\title{
Sustaining Natural-tourism's Competitiveness in Cianjur District
}

\author{
S. H. Hengky \\ Dept. of Management, Universitas Bina Darma, Indonesia \\ E-mail: hengky_halim@binadarma.ac.id; hengky_halim@yahoo.com.au
}

Received: January 10, 2019 Accepted: February 2, 2019 Published: December 15, 2019

doi:10.5296/emsd.v9i1.16044 URL: https://doi.org/10.5296/emsd.v9i1.16044

\begin{abstract}
Two botanicals garden with an area of 200.99 hectares become a lung of 48.68 million inhabitants on the island of West Java. The existence of the botanical garden is a natural tourist attraction for local residents. This study observes the performance of the environment-based botanical garden. In addition, questionnaires were collected whose purpose was to examine the extent of the attractiveness of natural tourism in the views and ratings of tourists that would, were, and after traveling. Which part is the main attraction of nature tourism? This qualitative - quantitative research was conducted for a year in in Cianjur District. Sampling is made randomly and purposively. In addition a focus group discussion was conducted involving a number of important stakeholders involved in this nature tourism.
\end{abstract}

Keywords: Natural- tourism's Competitive, Environment-based

\section{Introductions}

West Java Province has two botanicals garden namely the Bogor botanical garden and Cibodas. Their area is 120 and 80.99 hectares. The existence of a botanical garden is very important. In the district of Cianjur there is a botanical garden which is a choice of nature tourism enthusiasts. While, housing development is increasing to the island of Java Indonesia. Similarly, the number of motorized vehicles increased sharply. Both of these developments cause changes in land-use and vehicle pollution. The development of the population also increases every year. These three factors require improvements in quality of air, water, and recreational areas to support the lives of people living on the island. Cibodas botanical garden is a source of oxygen for life in West Java, which sustains $17 \%$ of the lives of living Indonesian.

Moreover, Mr. Johannes Ellias Teijsmann established Cibodas Botanical Garden on April 11, 1852. He is a botanist from the Netherlands, this place was named Bergtuin te Tjibodas which 
later developed and changed into Cibodas Botanical Garden. The purpose of establishing the Cibodas Botanical Garden at that time was for quinine plantations (Cinchona Calisaya). However, the soil structure is not suitable for the Cibodas Botanical Garden is devoted to the collection of typical wetland high vegetation. Starting in 2003 the status of the Botanical Gardens became a Technical Implementation Unit of the Plant Conservation Center. The location of this Botanical Garden is at the foot of Mount Gede and Mount Pangrango (Septyan, 2018).

Today's a number of diversity plants lost at an unprecedented level. It is difficult to cause a decrease in the number of plants - animals associated with ecosystem (Budeanu, Miller, Moscardo, \& Ooi, 2016). Therefore, it is (Boley, McGehee, \& Tom Hammett, 2017) necessary integrated welfare too (Hebdon, 2018). The diversity welfare (Bramwell \&atmos Lane, 2013)

Various parties, including the government, ignored the construction of botanical gardens to realize the development and management of sustainable botanical gardens. The function of the botanical garden, in addition to plant and animal conservation, is also for tourism activities. Tourism development aimed at creating income equality and equal opportunities in business. Improving the tourism sector will open job openings - business opportunities to increase people - government incomes will encourage related sectors to develop (Chen \& Sun, 2018).

There are several obstacles to the botanical garden such as factors related to external users of the Garden Plant Conservation accommodate the interest in visiting the botanical garden and external preferences for the results of Science. Besides, planning that did not look at all stakeholders' interests made they did not reach the target. Moreover, coordination that still needs to be improve on the stakeholders around the botanical garden environment. However, the amount of human resources, especially field technical personnel, which diminishes over time due to full-time employment (Chen \& Sun, 2018; Leung \& Baloglu, 2013).

This study will focus on studying the performance - main attractions of natural tourism in a botanical garden located in Cianjur Regency called the Cibodas botanical garden. This research conducted because of concerns that there would be a shift in the main function of the botanical-gardens which became the lungs of the Javanese population. In addition, it will also be a major factor of the attractiveness of natural attractions that attract tourists in deciding where they travel nature.

\section{Literature Review}

European experts document more than 100 years and stabilize nomenclature for more than 100 years and standardize environmental assessment (Brannstrom et al., 2017; Mucina et al., 2016; Wilson, Peet, Dengler, \& Pärtel, 2012). Although ultimately leads to the emergence of ecological aesthetics from attachments, relationships and holism where humans themselves come to understand their existence as closely related to non-human self (Neves, 2009).

The food sourced we eat came directly from plants or from animals that mostly consume plant-based diets. Almost all food comes from plants grown on farms. Unfortunately, the 
average American are no longer closely related to agriculture. In this area, there has been a transformation of $70 \%$ of them worked directly in agriculture. As a result, the population clustered in urban environments increasingly. Eighty percent of the total population lives in the city center. Most people no longer live near agricultural production and did not only to see it (Novy \& Dotson, 2015).

Based on harmony, the community, especially children that draw them to the botanical garden helps the government and managers to rethink the accepted educational practices about plants in the botanical garden (Rahm, 2018). The need for good understanding of the protection against the global environment by governments, institutions, non-governmental organizations contributed to botanical gardens need to strengthened, as well as government policies and commitments. Significant new resource commitments are important prerequisites (Blackmore, Gibby, \& Rae, 2011).

Shanghai Chenshan Botanical Garden collaborates with the local government in the Green City Master Plan to increase plant diversity and join rural garden projects. It also provides technical support for urban development by introducing urban horticulture and phytoremediation. As a botanical garden, it aims to attract and educate people with landscapes, seasonal flower shows, and cultural events. The garden helps visitors understand plant conditions and ways to protect plants in support of sustainable urban development (Chazdon et al., 2017).

Sustainability is a word that heard everywhere lately in terms the subject is energy, lodging, fishing or gardening. Plant conservation in the botanical garden still did not fully utilize for crop protection programs. Management decisions can easily help decision-making organizations interested in plant conservation that supported sustainable lifestyle programs to save the lives and environment of our children (Noureddine \& ZeinEddine, 2018).

Natural-tourism (Jovicic, 2019; Lee \& Jan, 2019; Roudi, Arasli, \& Akadiri, 2019; Saqib, 2019; Steiger, Scott, Abegg, Pons, \& Aall, 2019) sustainability is very important to the maintenance of local ecosystem services for carbon sequestration, biodiversity conservation, and climate regulation. It can affect atmospheric circulation patterns and composition on a regional to global scale. This biome-wide rehabilitation will greatly affect the carbon sequestration regime and preservation of biodiversity and have implications for economic development in the area (Sellmann \& Bogner, 2013).

Response analysis shows that respondents assess non-destructive resource used and increase visitor satisfaction as the highest value. Conversely, the role of regulating park law enforcement, management monitoring and stakeholder participation receives the smallest rating. The application of certain elements of natural-tourism requires social-cultural for the community relation and participation in safeguarding the conservation plant that supported by government plants and policies to increase natural conservation efforts due to urbanization and at the same time can increase economic contribution to local communities (Hengky \& Kikvidze, 2018).

The selection of resources affects the heterogeneity of botanical gardens and institutions and 


\section{Macrothink}

resources. The institution covers internal culture and defines economic behavior that is socially acceptable. A heterogeneity process modelled combines insight into resource-based views on an institutional perspective of organizational theory (Johansson, Greif, \& Fleischer, 2007; Oliver, 1997; Ratten, 2018).

\section{Methodology}

The research conducted from Jan 2017 to February 2018, which began with reviewing the literature to find relevant information related to the activities of tourists, travel agents, tour guides and departments related to botanical gardens (Figure 1). The data collected: 270 of the 300 respondents returned the questionnaire compiled in Indonesian and English (Each questionnaire consisted of 6 questions). The questionnaire distributed purposively among nine-groups (each group $=13$ respondents) (Table 1) from April - November 2017.

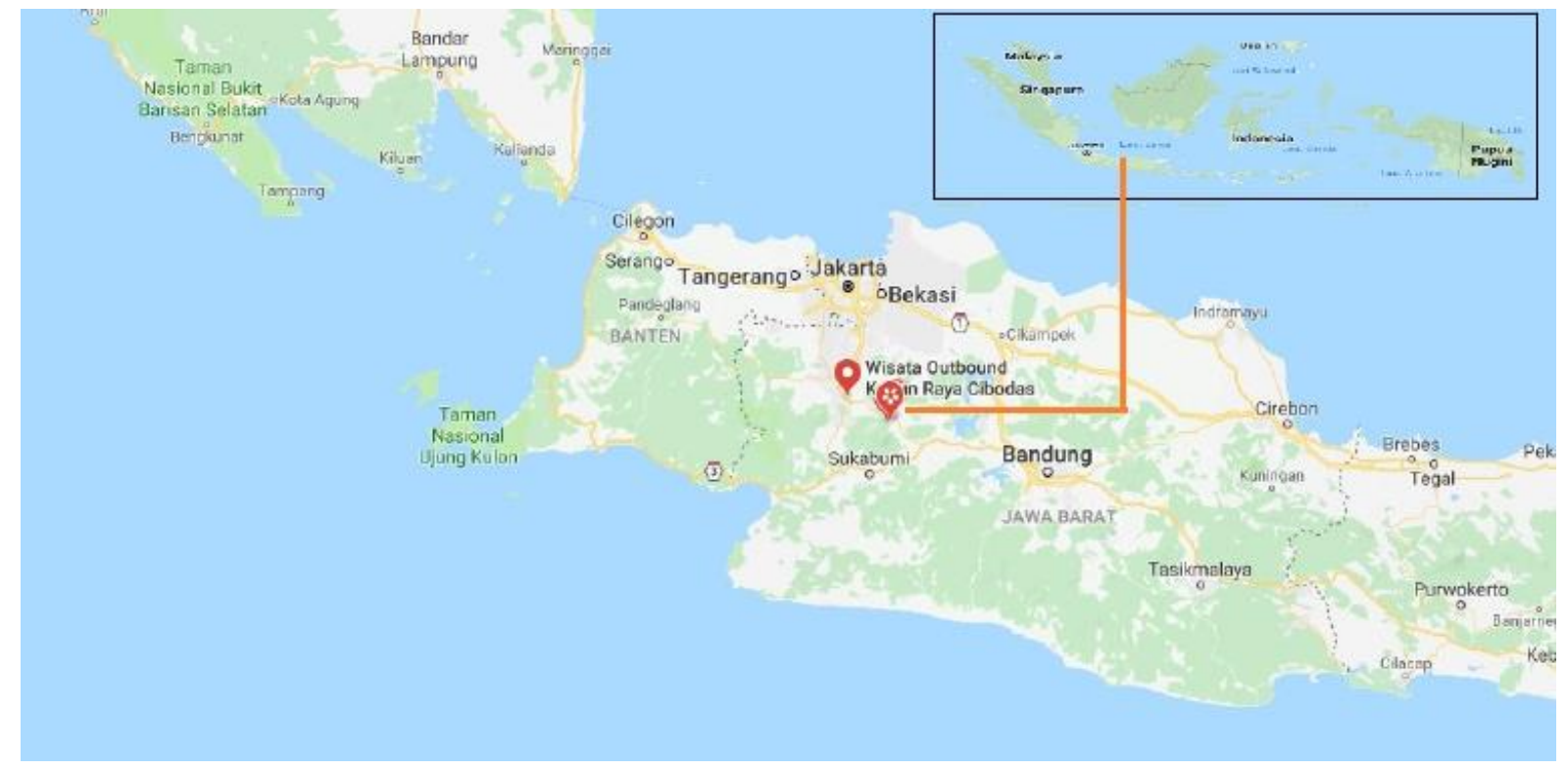

Figure 1. Cibodas Botanical Garden at an altitude of approximately 1,300 - 1,425 meters (above sea level), 84.99 hectares. The average temperature is $20.06{ }^{\circ} \mathrm{C}$, humidity is $80.82 \%$ and the average rainfall is $2,950 \mathrm{~mm}$ per year (Suhatman, 2010)

This is an indicator of the superiority in natural-tourism (Hall, 2019; Jovicic, 2019; Roudi et al., 2019; Saqib, 2019; Steiger et al., 2019; Thinh, Thanh, Tuyen, \& Hens, 2019) of botanical gardens and it's competitiveness (Christian, Gamayanto, Wibowo, \& Astuti, 2018; Mucina et al., 2016; Rahm, 2018; Sellmann \& Bogner, 2013):

1. Presents a natural atmosphere of the environment

2. Provides enormous benefits of human life

3. Conservation innovations

4. Make human life much better 


\section{Ml Macrothink}

5. Practices teach about plants

6. Involve the community relation

7. Utilize for crop protection programs

and

1. The ability to manage institutions and resources

2. Institution covers internal culture

3. Economic behavior - socially acceptable

4. Combines insight into resource-based views on an institutional perspective

All of these factors asked to the respondents to gather information about their opinions on the level of their agreement. The statement according to the significance level according to the Likert scale (Norman, 2010) through six levels. It namely on a scale of one (strongly disagree), and 6 (strongly agree ). In accordance with the consistency of the respondents, the questions were asked to them five times different times (Cavazos-Rehg et al., 2016).

The collected data processed by using content analysis. It will produce a Kappa coefficient value $(\mathrm{K})$ whose value meets the requirements if it exceeds 0.6. On the other hand, if the Kappa $(\mathrm{K})$ valued is below 0.6, the opinion of the respondent is not fulfilling the requirements. The opinions of the respondents that have quantified as kappa $(\kappa)$. All analyze performed using SAS / STAT software (SAS Institute Inc., NC, USA).

We also held two group discussions. First, 50 respondents discussed sustainable management at the Cibodas Botanical Garden. Second, 50 respondents discussed the competitive advantage of natural-tourism in the Botanical Gardens. These meetings are a general discussion (Lucero et al., 2018). These semi-structured discussion from the survey based on the questionnaire.

Number of respondent groups

Table 1. Group of respondents

\begin{tabular}{|l|c|}
\hline Cibodas travelled agent & 15 \\
\hline Ministry of Tourism staff & 11 \\
\hline Tourist bused driver & 12 \\
\hline Taxi driver / Grabe car & 16 \\
\hline General car driver & 12 \\
\hline Reception, reservation and & 14 \\
\hline Department of Infrastructure; Social and Environmental Impact analysis & 10 \\
\hline Member of the Cibodas local community & 11 \\
\hline Cibodas tour guide & 12 \\
\hline
\end{tabular}

The respondents discussed 11 indicators of the advantages of sustainable tourism. 


\section{Result}

This study found the Cibodas Botanical Garden (CBG) is natural-tourism (Coeffisien Kappa $=0.61$ ). $\mathrm{K}$ values $>0.6$ (Table 2). It is with the main strong indicators that natural atmosphere of the environment supported by providing enormous benefits of human life in conservation innovations and utilizing for crop protection programs. It became the main pint of interest of tourist. Besides offering natural attractions that are so beautiful with fresh air, CBG also has a collection of old and young trees with many variants. There are at least 5,831 examples of plants from 1, 206 species that can be found on site. Shifting to the greenhouse, there are various types of cactus and orchid plants, including rare plants that you can find while visiting here. There are at least 4,000 examples of plants with 350 cactus and 360 orchids in the greenhouse. Some locations in $\mathrm{CBG}$ that are interesting for tourists to visit include greenhouses, rivers, cherry tree gardens, lakes, fountains, and water falls.

Table 2.

\begin{tabular}{|l|l|c|}
\hline Natural-tourism & Value & Freq \\
\hline Presents a natural atmosphere of the environment & 34 & 0,1753 \\
\hline Provides enormous benefits of human life & 31 & 0,1598 \\
\hline Conservation innovations & 28 & 0,1443 \\
\hline Make human life much better & 25 & 0,9259 \\
\hline Practices teach about plants & 23 & 0,1186 \\
\hline Involve the community in relation to place, land and the world & 26 & 0,1340 \\
\hline Utilize for crop protection programs & 27 & 0,1392 \\
\hline Coefficient Kappa & 0,6158 & \\
\hline
\end{tabular}

Table 3.

\begin{tabular}{|l|l|c|}
\hline Natural-tourism Competitiveness & Value & Freq \\
\hline The ability to manage institutions and resources & 29 & 0,2636 \\
\hline Institution covers internal culture & 27 & 0,2455 \\
\hline Economic behavior - socially acceptable & 30 & 0,2727 \\
\hline Combines insight - resource-based views on an institutional perspective & 24 & 0,2182 \\
\hline Coefficient Kappa & 0,6111 & \\
\hline
\end{tabular}

The natural tourism competitiveness of CBG validated in Table 3 by the results of the tabulation of the Kappa Coefficient $=0.61$, the indicator of economic behavior - social acceptable is important. It proofed the competitiveness of natural tourism in the CBG. Another indicator is that this tourist place is very cool and fresh. The temperature is around 17-27 degrees Celsius. CBG has an area of around 80 hectares and stores various objects that it could be enjoy or visit. Sakura Park located 100 meters from the entrance is the most favorite object of visitors. As in Japan, this Sakura tree can grow well on CBGs. This is due to the contour of the land, climate, and altitude of the place almost the same as the natural 
habitat. Within a year, Cherry Blossoms in this garden can bloom twice and each time blooms for four days, while the blooming time is around January-February and July-August.

In Sakura Park, there are 7 types of Sakura trees with a total of 435 trees. The garden has 134 types of mosses. Most of them come from around the CBG. This garden also has 3 types of Rhododendrons, namely Rhododendron Javanicum (Java), Rhododendron Macgregoriae (Papua), and Rhododendron Mucronatum (Japan).

In this CBG, there are also two waterfalls, namely Cibogo and Ciismun. Cibogo waterfall which has a height of about 15 meters and is located right next to the Cibodas Botanical Garden Sakura Park area. The atmosphere still feels very natural because not many people know of its existence. To go to Cibogo waterfall, tourists are expected to be careful because the roads are slippery and a bit steep. This waterfall has a pool with a size that is not too large, but has a fairly heavy discharge. While, Ciismun waterfall is located at an altitude of about 25 meters, with a waterfall area of 5 meters, the water flow down from the corner of the Agropolitan hill meeting with Cibodas Hill as high as 1275 meters above sea level. The tourists enjoy the freshness directly. Located in the CBG area. At the location of the waterfall, we can take a bath or just soak the feet in the bottom puddle. The scenery is also no less interesting. Falling water will make the atmosphere cheerful again and again reflect the thoughts of the visitors. In this Botanical garden also has a greenhouse that stores various collections of plants. Greenhouses made to maintain the temperatures needed by plants in them as in their natural habitat. In addition, It also a greenhouse functions to increase the collection of botanical garden plants. There are three types of plants in greenhouses, namely orchids, cactus, and succulent plants.

In addition, still in the CBG area, there is one unique waterfall named "Panca Weuleuh". Panca Weuleuh literally means "Five Tired". This word also appears in several versions, some interpreting tired every five minutes, there is also a mention of five climbs that make you tired. Access to the waterfall is quite difficult because it is located at an altitude of 2,200 meters above sea level.

That is water tourism in the form of waterfalls in the Cibodas area. The perfect location to calm the mind and freshen up for tourists.

Nevertheless, there is the Rawa Gede in the Mandalawangi Cibodas Camping Ground (MCCG) area. Its location is quite hidden because it is located to the north of the camping area. The tourists must pass through the forest and footpath first. Having a height of 11 meters, this one waterfall plays an important role to irrigate the rice fields and gardens of the people who live in the Mandalawangi area. The MCCG has a natural feel that is still fresh, cool and beautiful. It is suitable for camping tours for adventurers and outdoor enthusiasts. It has geographical conditions consisting of rivers, lakes, gravel soils that can easily absorb water, grass, bushes, trees, forests and relatively cold temperatures. This makes for good terrain and is also ideal for camping. In addition, the camping area is wide and varied, so we can choose the ideal campsite according to the needs and tastes of tourists.

A number of other locations that can be visit are the lake in the middle of the botanical garden, 


\section{Ml Macrothink}

Clear River, moss garden, collection of medicinal plants, fern collections, fountains located near to the gate three (3), Araucaria road, and Rhododendron Park. Just like the Bogor Botanical Gardens, here are also rare Giant Carrion Flowers that they bloom at certain times. The Carrion Flower is located north of the greenhouse. Collection of plants in botanical gardens that are typical of tropical upland plants is also diverse. There are around 4000 examples of plants from 98 species of Cactus, 262 species of Orchids, and 71 types of succulent collections. The Botanical Garden also collected 74 types of ferns. It approximately 164 types of medicinal plants. With a large collection of plants in the garden, visitors that come not only recreation but also add insight into various types of plants in Indonesia and even abroad.

The vision of the CBG is to become one of the best botanical gardens in the world in the field of tropical plant conservation, especially wet tropical highland plants, research, environmental education services, tourism, and environmental services. In order to realize this vision, the manager of the CBG is very concern about all aspects including managing institutional perspective and resource-based view of the function of environmental services. It is an important factor of developing competitiveness. Some of the studies include estimation of carbon stocks and biomass in Cibodas Biosphere Reserve, and the association for carbon stocks and plants.

Another effort as a form of environmental services in the CBG is a strategy of restoration rehabilitation of degraded's land and prone to landslides in the Citarum and Cisadane River Basin ecosystems as climate change mitigation efforts. The rise of development around the CBG Conservation Area, West Java, threatens the sustainability of ecosystems, especially plants. Even though, it cannot be proven directly, the most obvious impact is the increase in average temperature from $19-21{ }^{\circ} \mathrm{C}$ (Mutiara, 2018). The temperature changes that began to be fall for two years ago were not only causing the weather to get hotter, but also potentially threatened the plant growth cycle. In addition, there is a shift in the time of flowering and fertilization of cherry blossoms. Usually, the process occurs to January - February. However, it has now shifted to March. In fact, the cherry blossoms are now much shorter. Previously, the flowering period lasted for a week. In 2016, cherry blossoms only bloom within three days.

The main problem that it must be deal with immediately is the threatened plant collection of the CBG. A part of them (46 of 1,851 species) is on the conservation program. These endangered plants are diverse, but generally come from orchid species spread in various parts of Indonesia. In addition, there are also rare plants of the type of lianas or vines that grow on other plants. Among them is Kadsura.

Rare plants that are still in the botanical garden. There are various other collections of plants are actually great potentials that they need to be preserved. In fact, it should continue to be developed. Generally, Liana plants that used as shelter for pergola. It used as a place for ecotourism in the botanical garden. 


\section{Conclusion}

This study found the CBG categories natural tourism. Natural atmosphere of the environment become the first priority of tourists interested. While, the management of the CBG could implement the competitiveness concept on managing and controlling natural-tourism but they have a handicap to deal the threatened plant collection on their conservation program. Some of the plants in the conservation program had threatened with extinction. In general, these plants come from orchid species that spread in various regions in Indonesia. In addition, there are a number of rare plants endangered species.

Therefore, botanical garden managers need to increase their capacities and ability is always be oriented to the expectations of tourists in accordance with their competencies, especially in public services in the future. Furthermore, planning that takes into account the resources of the botanical garden. So that, the target set is more realistic. Moreover, it is necessary to increase communication between stakeholders that made the policy harmonization occurs. Nevertheless, the recruitment of accountable and competent employees, adjusted to the budgeting capabilities of the botanical garden.

\section{Acknowledgement}

The author would like to thank the SHINE Institute for helping to distribute questionnaires to respondents. On this good opportunity, the authors would also like to thank the editors and anonymous reviewers who have supported the publication process of this journal.

\section{Reference}

Blackmore, S., Gibby, M., \& Rae, D. (2011). Strengthening the scientific contribution of botanic gardens to the second phase of the Global Strategy for Plant Conservation. Botanical Journal of the Linnean Society, 166(3), 267-281.

https://doi.org/10.1111/j.1095-8339.2011.01156.x

Boley, B. B., McGehee, N. G., \& Tom Hammett, A. L. (2017). Importance-performance analysis (IPA) of sustainable tourism initiatives: The resident perspective. Tourism Management, 58. https://doi.org/10.1016/j.tourman.2016.10.002

Bramwell, B., \& Lane, B. (2013). Getting from here to there: systems change, behavioural change and sustainable tourism. Journal of Sustainable Tourism, 21(1), 1-4.

https://doi.org/10.1080/09669582.2012.741602

Brannstrom, C., Gorayeb, A., de Sousa Mendes, J., Loureiro, C., Meireles, A. J. de A., Silva, E. V. da, ... Oliveira, R. F. de. (2017). Is Brazilian wind power development sustainable? Insights from a review of conflicts in Ceará state. Renewable and Sustainable Energy Reviews, 67, 62-71. https://doi.org/10.1016/J.RSER.2016.08.047

Budeanu, A., Miller, G., Moscardo, G., \& Ooi, C. S. (2016). Sustainable tourism, progress, challenges and opportunities: An introduction. Journal of Cleaner Production, 111.

https://doi.org/10.1016/j.jclepro.2015.10.027

Cavazos-Rehg, P. A., Krauss, M. J., Sowles, S., Connolly, S., Rosas, C., Bharadwaj, M., \& 
Bierut, L. J. (2016). A content analysis of depression-related tweets. Computers in Human Behavior, 54, 351-357. https://doi.org/10.1016/J.CHB.2015.08.023

Chazdon, R. L., Brancalion, P. H. S., Lamb, D., Laestadius, L., Calmon, M., \& Kumar, C. (2017). A Policy-Driven Knowledge Agenda for Global Forest and Landscape Restoration. Conservation Letters, 10(1), 125-132. https://doi.org/10.1111/conl.12220

Chen, G., \& Sun, W. (2018). The role of botanical gardens in scientific research, conservation, and citizen science. Plant Diversity, 40(4), 181-188.

https://doi.org/10.1016/J.PLD.2018.07.006

Christian, H., Gamayanto, I., Wibowo, S., \& Astuti, Y. P. (2018). The Impact \&amp; Innovation of E=K.MC2 in Singapore Botanic Garden (SBG): The Business Strategy to Gain Competitive Advantage. Journal of Economics and Management Sciences, 1(1), 166.

https://doi.org/10.30560/jems.v1n1p166

Hall, C. M. (2019). Constructing sustainable tourism development: The 2030 agenda and the managerial ecology of sustainable tourism. Journal of Sustainable Tourism, 27(7), 1044-1060. https://doi.org/10.1080/09669582.2018.1560456

Hebdon, B. (2018). 10 great botanical gardens around the world: readers' tips | Travel | The Guardian. [Online] Available:

https://www.theguardian.com/travel/2018/aug/16/10-great-botanical-gardens-around-world-re aders-travel-tips

Hengky, S., \& Kikvidze, Z. (2018). Tourism sustainability in the Bogor Botanical Gardens, Indonesia. Urban Forestry \& Urban Greening, 30, 8-11.

https://doi.org/10.1016/J.UFUG.2018.01.007

Johansson, G., Greif, A., \& Fleischer, G. (2007). Managing the design/environment interface: studies of integration mechanisms. International Journal of Production Research, 45(18-19), 4041-4055. https://doi.org/10.1080/00207540701474823

Jovicic, D. Z. (2019). From the traditional understanding of tourism destination to the smart tourism destination. Current Issues in Tourism, 22(3), 276-282.

https://doi.org/10.1080/13683500.2017.1313203

Lee, T. H., \& Jan, F.-H. (2019). Can community-based tourism contribute to sustainable development? Evidence from residents' perceptions of the sustainability. Tourism Management, 70, 368-380. https://doi.org/10.1016/J.TOURMAN.2018.09.003

Leung, X. Y., \& Baloglu, S. (2013). Tourism Competitiveness of Asia Pacific Destinations. Tourism Analysis, 18(4), 371-384. https://doi.org/10.3727/108354213X13736372325876

Lucero, J., Wallerstein, N., Duran, B., Alegria, M., Greene-Moton, E., Israel, B., ... White Hat, E. R. (2018). Development of a Mixed Methods Investigation of Process and Outcomes of Community-Based Participatory Research. Journal of Mixed Methods Research, 12(1), 55-74. https://doi.org/10.1177/1558689816633309 
Mucina, L., Bültmann, H., Dierßen, K., Theurillat, J.-P., Raus, T., Čarni, A., ... Tichý, L. (2016). Vegetation of Europe: hierarchical floristic classification system of vascular plant, bryophyte, lichen, and algal communities. Applied Vegetation Science, 19, 3-264. https://doi.org/10.1111/avsc.12257

Mutiara, P. (2018). Development Threatens Cibodas Ecosystem. [Online] Available: http://mediaindonesia.com/read/detail/100501-pembangunan-ancam-ekosistem-cibodas

Neves, K. (2009). Urban Botanical Gardens and the Aesthetics of Ecological Learning: A Theoretical Discussion and Preliminary Insights from Montreal's Botanical Garden. Anthropologica, 51, 145-157. https://doi.org/10.2307/25605463

Noureddine, O. H., \& ZeinEddine, R. B. (2018). American Scientific Research Journal for Engineering, Technology, and Sciences. In American Scientific Research Journal for Engineering, Technology, and Sciences (ASRJETS) (Vol. 42). [Online] Available:

http://asrjetsjournal.org/index.php/American_Scientific_Journal/article/view/3989

Novy, A., \& Dotson, D. (2015). Botanical Gardens Are Well Positioned to Share Agriculture with the Public. CSA News, 60(8), 40. https://doi.org/10.2134/csa2015-60-8-13

Oliver, C. (1997). Sustainable competitive advantage: combining institutional and resource-based views. Strategic Management Journal, 18(9), 697-713.

https://doi.org/10.1002/(SICI)1097-0266(199710)18:9<697::AID-SMJ909>3.0.CO;2-C

Rahm, J. (2018). Youths' navigations of botanical gardens: bids for recognition, ways to desettle practice. Environ. Educ. Res., 1-13. https://doi.org/10.1080/13504622.2018.1469731

Ratten, V. (2018). Social innovation in sport: the creation of Santa Cruz as a world surfing reserve. International Journal of Innovation Science, IJIS-12-2017-0135.

https://doi.org/10.1108/IJIS-12-2017-0135

Roudi, S., Arasli, H., \& Akadiri, S. Saint. (2019). New insights into an old issue - examining the influence of tourism on economic growth: evidence from selected small island developing states. Current Issues in Tourism, 22(11), 1280-1300.

https://doi.org/10.1080/13683500.2018.1431207

Saqib, N. (2019). A positioning strategy for a tourist destination, based on analysis of customers' perceptions and satisfactions. Journal of Tourism Analysis: Revista de Análisis Turístico, 26(2), 131-151. https://doi.org/10.1108/JTA-05-2019-0019

Sellmann, D., \& Bogner, F. X. (2013). Climate change education: quantitatively assessing the impact of a botanical garden as an informal learning environment. Environmental Education Research, 19(4), 415-429. https://doi.org/10.1080/13504622.2012.700696

Septyan, A. R. (2018). Enjoy Natural Beauty at Cibodas Botanical Garden. [Online] Available: https://foresteract.com/menikmati-keindahan-alam-di-kebun-raya-cibodas/

Steiger, R., Scott, D., Abegg, B., Pons, M., \& Aall, C. (2019). A critical review of climate change risk for ski tourism. Current Issues in Tourism, 22(11), 1343-1379. 


\section{Macrothink

https://doi.org/10.1080/13683500.2017.1410110

Suhatman, A. (2010). Cibodas Botanic Gardens. [Online] Available:

https://www.bgci.org/garden.php?id=40

Thinh, N. A., Thanh, N. N., Tuyen, L. T., \& Hens, L. (2019). Tourism and beach erosion: valuing the damage of beach erosion for tourism in the Hoi An World Heritage site, Vietnam. Environment, Development and Sustainability, 21(5), 2113-2124.

https://doi.org/10.1007/s10668-018-0126-y

Wilson, J. B., Peet, R. K., Dengler, J., \& Pärtel, M. (2012). Plant species richness: the world records. Journal of Vegetation Science, 23(4), 796-802.

https://doi.org/10.1111/j.1654-1103.2012.01400.x

\section{Copyright Disclaimer}

Copyright for this article is retained by the author(s), with first publication rights granted to the journal.

This is an open-access article distributed under the terms and conditions of the Creative Commons Attribution license (http://creativecommons.org/licenses/by/3.0/). 